\title{
Access and Benefit Sharing Effectiveness: International Environmental Law Implementation at the Domestic Ethiopian Level
}

\author{
Abebe Kebede Jalleta \\ Law School, Research Institute of Environmental Law, Wuhan University, Wuhan, China \\ Email: abekebjalle@gmail.com
}

How to cite this paper: Jalleta, A. K. (2021) Access and Benefit Sharing Effectiveness: International Environmental Law Implementation at the Domestic Ethiopian Level. Beijing Law Review, 12, 485-508. https://doi.org/10.4236/blr.2021.122027

Received: March 31, 2021

Accepted: May 9, 2021

Published: May 12, 2021

Copyright $\odot 2021$ by author(s) and Scientific Research Publishing Inc. This work is licensed under the Creative Commons Attribution International License (CC BY 4.0).

http://creativecommons.org/licenses/by/4.0/

\begin{abstract}
Access and Benefit Sharing (ABS) in international environmental laws (mainly, but not limited to, biodiversity) converges with human rights instruments on indigenous people. State parties should take legislative, administrative, and practical measures to realize the ABS regimes. This article argues that there are normative and practical gaps including confusing ABS with compensation in Ethiopian domestic laws and actual implementation, while ABS itself is not well understood. The article finally recommends legal amendments and policymakers' political move to comply with the country's international duty.
\end{abstract}

\section{Keywords}

Access and Benefit Sharing, Indigenous People, International Environmental Law, Intra-State

\section{Introduction}

Many researchers in International Environmental Law (IEL) and Human Rights Agreements (HRAs) have dealt with issues of ABS (including, but not limited to, Arjjumend, 2018; Morgera, 2016a; Petrov and Tysiachniouk, 2019). Their works discuss the concepts, contents, and status of ABS at international law (Morgera, 2016a). Given the normative convergences of IEL and HRAs, further study on ABS effectiveness at the national level is pressing (Morgera, 2017). Particularly, proper identification of its features, scopes, beneficiaries, and objects of application in domestic laws is one of the detriments of implementing global duties (Morgera, 2017). This obstacle emanates from the vagueness of the ABS concept 
itself. Only a few multilateral treaties are well developed and address it, especially emphasizing the genetic resources, though ABS applies to other Natural Resources (NRs), too (Convention on Biological Diversity (CBD), 1992 article 1, the Nagoya protocol, 2010 article 5). The CBD and its associated legally binding and non-binding international instruments more developed the ABS concepts (Petrov \& Tysiachniouk, 2019: p. 1). Some other indigenous people-based treaties also have critical ABS provisions that can align with these IEL regulations although they magnify human rights to compensation of land holdings and immovable properties related to land. The United Nations Declaration on the Rights of Indigenous Peoples (UNDRIP) and the 1989 Indigenous and Tribal Peoples Convention, No.169 (ILO/169) can be prominent examples in this regard (ILO/169, Article 15). Therefore, the growing pressure on landed resources of these people's areas for development requires statutory interpretation and further analysis for the understanding and general application of ABS.

Disparity on resource ownership views between state and indigenous people and failure of applying laws as they are on the paper at the national level is another detriment (Sand, 2017). On the one hand, national states use their sovereign power to use the natural resources to achieve sustainable development goals (SDGs) (World Bank, 2015). The 2030 SDGs commitment encourages this option, while it should be handled per IEL and HRAs that provide for lifting the vulnerable from their livelihood hardships (Arjjumend, 2018). This political commitment to be abiding by the law calls for ABS in addition to compensating the people who depend on such resources for their livelihoods or own property on the resources (UNDRIP, 2007: Article10). Because compensation may not sufficiently address the overall means of existence for the people in their original domicile (Petrov \& Tysiachniouk, 2019). On the other hand, ABS is a critical concept to upgrading the way of life of communities affected by the extractive industry in general and indigenous people in particular. In this regard state policy and administrative measures should be in line with ABS provided by law (Petrov \& Tysiachniouk, 2019). Also, domestic laws and state practices should reveal ABS effectiveness on environmental protection with the view of sustaining it to the future generation (Petrov \& Tysiachniouk, 2019). These variations, in general, indicate international duty implementation gaps at the domestic level.

Normative gaps in a legal regime are about the unruliness of the rule of law (Alces, 2003). If the law loses its capacity of acceptance or is vague, it remains unperformed. On this point, K. Gorobets argues that domestic and international rule of law demands practical authority which shall meet justified and realizable conditions (Gorobets, 2020: p. 247). In his words, as I quote: "the authority of the law becomes normative if its existence is the reason for conforming actions and for excluding conflicting considerations, [where] authority is the relationship between the state and the individuals or collective," while reasons are facts or issues that need accomplishment (Gorobets, 2020: pp. 237-238). Hence, ABS is one of the legal principles that need advancement from both domestic and in- 
ternational rules of law.

This article aims at identifying and analyzing normative gaps in Ethiopia's national laws, if any, relating to fair and equitable ABS and to figure out whether these gaps can be remedied to induce Ethiopia to comply better with its international legal obligation. The organization of the article is as follows. First, I highlight an interplay among the state, a company, and the Oromo indigenous people on the gold extractive company used as indicating case in this article following this brief introduction. The third section follows with an overview of the ABS concepts and legal convergence including its definitions and interpretations. Section four analyses whether the Ethiopian laws comply with ABS provisions of international law. Section five deals with actual realization including policy directions and administrative decisions. Section six evaluates whether the consequences of extractive industry on the environment and ecological impacts are made parts of the ABS. In the last section, I summarize the potential gaps and conclude with proposed two recommendations on amending the national laws and policy makers' initiatives to enforce the international instruments at the national level.

The methods followed in this article are combinations of comparative, evaluative, contextual, and descriptive methods. I use a comparative approach to analyze the domestic legislation and its actual implementation in light of international law acceded and ratified by Ethiopia and practices from other jurisdictions to learn from the differences or similarities. An evaluative approach helps to test the effectiveness of the ABS at the national level. The contextual method is also used to critically analyze the policy documents and political decisions in the MIDROC goldmine case chosen as the subject of this study and identify the existence of practical compliances with laws. A review of prior studies to draw a lesson, examine legislation, and secondary information to know the standard of domestic laws compared to international instruments was also made. I also drew lessons from some African countries' case and research reports whose local communities benefitted from mining and exist in similar communal settings.

\section{The Problem Identified}

The world nations reaffirmed their political commitment to bring development and end poverty that accommodates the vulnerable including indigenous people in the 2030 SDGs. The 17 SDGs and all of their targets are critical in this regard, while SDG2 and 15 are particular environmental agendas showing parties' political commitments to address ABS to these parts of the society from the sustainable use of natural resources (Boer \& Hannam, 2021). The commitments were entered to implement IEL duties provided under the CBD (Article, 1) and the Nagoya Protocol (Articles 9, 10 \&12) in combination with the rights protected under ILO-169 (Article, 15 (2)) and some non-legally binding declarations like UNDRIP (preamble). Particularly, the use of landed resources along with conservation of biodiversity takes into account the role and benefits of indigenous 
people from the ecosystem (UNDRIP, Article 32; CBD, Article1 \& 2; Agenda 21, chapter 26).

Developing countries have aggressively increased availing their landed NRs for investment more than ever using their sovereign power over such resources following entering into force of the SDGs (Barrel, 2016). They have been issuing their prime lands to commercial farming, floriculture, biofuel, and mining industries by either expropriating from holders or state lands through lease arrangements or concession contracts (Ethiopian National Planning Commission (NPC) \& Central Statistical Agency (CSA), 2017). For instance, the Ethiopian government had been transferring communal and individual holdings to others in the name of investment (NPC \& CSA, 2017: pp. 40-50). Laga-Dambi goldmine, a rich site with various NRs found in the Guji zone of Oromia regional state (Oromia) is one of them. The government let it to MIDROC goldmine company, through a concession contract for 20 years in 1997 after extracting more than 55 tons of placer gold by itself (World Bank, 2014; Ministry of Mines \& Petroleum (MOMP), 2019). The leased land has over 82 tons of deposits and an average 3.6-ton production capacity of gold per year to MIDROC (MOMP, 2019).

However, encroaching indigenous people's land and NRs threatened their survival in many ways. This site has been under the ownership and management of the Oromo indigenous people, who are affected by this move. Like any indigenous peoples, they have been leading stable life using the land communally for grazing, farming, residence, and traditional mining, while they use the forest for hunting, honey production, ritual, and spiritual purposes (EPHI \& MOMP, 2018). They also still exist there. But aliens and the state itself disturbed their established socio-economic and cultural settings due to this extractive plant (MOMP, 2019). The company expanded the mining site's land size with government decisions from time to time, which was 15.8 hectares (ha) in 1988 and grew to $485 \mathrm{ha}$ in 2018 (MOMP, 2019: pp. 8-11). This measure minimized land for the mentioned purposes and damaged the cultural heritage sites of the indigenous people (MOMP, 2019: pp. 40-48). Also human and animal health, environmental media pollution, deforestation, and land degradation worsened the peoples' livelihood vulnerability due to the extractive activity (EPHI \& MOMP, 2018: pp. 47-69). However, the company reaped \$ETB 22.25 billion within 18 years (1998-2016) from the sale of gold and silver extracted from this land (NPC \& CSA, 2017). The question is whether there is a legal basis to address ABS from minerals other than GRs under international law to influence Ethiopia to comply with its international law duty.

\section{ABS in Intra-State Relations: An Overview}

Systematic and comprehensive understanding, as well as legal backing and critical implementation of the ABS concept, has become a critical concern, especially in areas where extractive activities have been growing like developing countries and the Arctic (Petrov and Tysiachniouk, 2019). International and regional laws 
extend $\mathrm{ABS}$ to indigenous people in the form of procedural and substantive rights, emphasizing those who have been administering the resources, while it was advocated for developing countries under colonial rules to retain sovereignty over their natural resources (UNDRIP, Article 10 \& 28 (1); ILO/169, Article 15 (2); CBD, Article 15 (7)). The global community's concern about ABS in sustainable development activities is also related to response to the harmful effects of extractive industries, contributions of the indigenous people's knowledge to manage the NRs for long and benefit them from the development (UNEP, 2006). And the need to link it with sustainable development through wise use of natural resources and environmental protection flourished different discourses among legal literature works (ILA, 2002).

One debate is based on its current legal status. Some legal scholars describe that ABS is among the general principles of international law as both developed and developing nations reached a consensus on it (Cabrera \& Fred-Perron, 2018). And others argue that it has become a cross-cutting issue and captured customary law status requirements though it has short life compared to other concepts, while some still argue against considering ABS as a specific principle and customary international law (Morgera, 2016a). Indeed, it is addressed in many international instruments and a few case laws since its first emergence in the Universal Declaration of Human Rights (UDHR) in 1948, followed by treaties such as the ILO/169, the law of the sea (UNCLOS), and the CBD including some soft laws (Welfare Council v. Kenya (Endorois case), 2003: Para. 228; CBD, Articles 1, 15 (3) \& (7); ILO/169, Article 15 (2)).

ABS appears with many features in these laws, including objective, obligation, rights, safeguards, and mechanisms (Morgera, 2016a: p. 354). It is regarded as the third objective of $\mathrm{CBD}$, where it is more developed and advanced, including in the Nagoya protocol and its guidelines (CBD, Article 1). Also, it is a legal obligation in these instruments (CBD, Articles 15 (7) \& 8 (j); Nagoya Protocol, Article 5). ABS appears as right in Article 15 (2) of the ILO, the UNDRIP, and the International Treaty on Plant Genetic Resources for Food and Agriculture (ITPGRFA, Article 9) ${ }^{1}$. It also has its base in these instruments, including the sea law (UNCLOS), to address NRs benefits and serves as a mechanism (Morgera, 2017: pp. 7-12). ABS provisions have been transplanted from ILO, into some countries' domestic laws, though some are not member states to ILO, and other conventions in addition to its contribution to interpreting other hard and soft laws (Morgera, 2016a: pp. 355-357). For instance, it is encapsulated as a built-in element of indigenous people's land and natural resource rights in ILO and later became part of UNDRIP and the American Human Rights Convention. Also, the contextual use of ABS provisions in these global instruments helps realize indigenous people's rights and ABS's overall applicability (Nagoya Protocol, Article 5 (4), annex, articles 6.2, 7, 8, 12.3 (b) \& 18.2). The essence of including ABS's concept in these MEAs and HRAs indicates its ${ }^{1}$ International Treaty on Plant Genetic Resources for Food and Agriculture (ITPGRFA), $31^{\text {st }}$ session, Conference of the FAO, 3 November 2001, Article 9. 
vitality and critical importance to realize the indigenous people's agenda. And it signals the state parties to accomplish their legal obligations of benefitting these people from resources they used to own or manage. But still, there is vagueness on four points that account for lack of implementation in many jurisdictions, namely the concept of ABS, the scope of its application, kinds of benefits, and natural resources to be sources of $A B S$.

ABS itself is not a well-understood concept to uniformly implement it, while it is a young concept and addresses many issues. Many states and actors are alleged to lack clarities on it and left behind to implement their international law obligations at the national level (Morgera, 2016a: p. 361). On this point, Morgera argues that 'the concept is not understood, fully developed, and not made satisfactorily operational.' Its scope also covers vast extremes that extend from global to local community relations. It covers, among many, inter-state relations concerning taking their part from the fruits of humankind's common heritage like deep seabed and celestial bodies resources (Medaglia \& Perron-Welch, 2019); intrastate relations (benefit-sharing between federal and regions, or states and communities); community-private company and intra-community relations that bases on customary law, national and international law (Morgera, 2016a: p. 355). This article focuses on the intra-state interaction-related benefits.

Promising ABS developments in international and regional regimes are bases on norm diffusion to domestic laws in most cases, though sometimes the reverse can work. Indigenous people have inherent rights and depend mainly on their lands and environmental media for their livelihood and need elaborate lists of benefits that enhance and protect this right and their attachment to their ancestral lands (UNDRIP, Article 26 (3)). States and industries must consult in good faith and make indigenous people partners and participate in decisions on benefits they should get from the upcoming projects, rather than giving them a portion of the share (Morgera, 2016a). And Morgera adds that the fruits to be shared should be culturally appropriate and indigenously identified to prevent the divisive or disruptive nature of its consequences (Morgera, 2016a: p. 366). However, except for some developments that require extractive companies' due diligence acts to respect human rights, there are no detailed lists of benefits in the international regimes governing their rights (Morgera, 2017: p. 7). ABS's status as a right and safeguard in intra-state relations is based upon specific situations of indigenous people concerned, which calls case by case decisions, albeit explicit legal provisions (The Endorois case, para. 228). Domestic laws explicitly provide this approach on non-monetary benefits, as shown in Ethiopia's law on genetic resources ABS implementing the law ${ }^{2}$. This approach emanates from a lack of listing major benefits kinds, though it is difficult to list all of them.

Some IEL regimes list detailed kinds of benefits and the resources upon which ABS applies. The Nagoya protocol categorizes it into monetary and non-monetary

${ }^{2}$ Proclamation No. 482/2006, Access to Genetic Resources and Community Knowledge and Community Rights Proclamation, Negarit Gazette, $13^{\text {th }}$ Year, Addis Ababa, 27, February 2006, Article 18 (1). 
benefits (The Nagoya protocol, Annex \& Article 5 (4)). The protocol lists the non-monetary benefits as: "research and development results, collaboration in scientific research and development, participation in product development, admittance to ex-situ facilities and databases, as well as capacity building and training" (Annex, Articles $2(\mathrm{a}-\mathrm{c})$ and $(\mathrm{e}) ; 2(\mathrm{~d}),(\mathrm{g}-\mathrm{i}),(\mathrm{n})$ and $(\mathrm{j}))$. The CBD also includes funding and technology transfer into these lists (CBD, Articles 1 and 19). The protocol even provides details of monetary (economic) benefits. Among many, 'joint ventures/ownership status, profits in the form of access fees, upfront or milestone payments, royalties, license fees, and financial resources contributing to conservation efforts (such as special fees to be paid to conservation trust funds)' (Nyamwaya, 2013). The UNCLOS also provides for monetary benefits under article 140.

In short, the concept of $\mathrm{ABS}$ is needs deep understanding. Its multifarious features should be more clear and get implemented at the domestic level as expected. The foregoing discussion shows that ABS has legal grounds for the enforcement of political commitments echoed for indigenous people under the 2030 SDGs. However, concept vagueness and legal gaps in other treaties can be remedied by statutory interpretations or analogical applications of the ABS provisions to similar laws and natural resources so that indigenous people shouldn't be left behind from getting equitable shares of the fruits of resources under their custody. The next sections deal with the effectiveness of adopting these international law's legal concerns into federal laws, policies, or administrative measures of Ethiopia on ABS, emphasizing extractive industries.

\section{Legal Effectiveness: National Implementation}

Ethiopia is a state party to the CBD and Nagoya Protocol, which are legally binding $^{3}$. It has also been committed to many international soft laws, to mention a few of them, Agenda 21, the Reo declaration, etc. The effectiveness of its commitments to these instruments requires implementation at the domestic level through its national laws, policies, programs, and actual demonstration of fair and equitable ABS realization in practice (Bodansky, 2010).

The legal backing of NRs use helps to regulate the development and protect indigenous people's rights as their activities reflect their identity and benefit to sustain them (Zmyvalova, 2018). NR is a broader concept comprising living (genetic) and non-living resources like minerals, land, soil, and water, on which the living resources survive (Zheng, 2019). There is no governing definition of NRs in Ethiopian laws, except one can read it through the term: "environment," including NRs. This section analogically uses legal coverages and scholarly literature written on ABS concerning biological diversity, indigenous peoples rights, and the sea law to get academic clarity on ABS realization from the mining operations context. Accordingly, it deals with ABS effectiveness (legal, behavioral,

${ }^{3}$ Note that Ethiopia ratified CBD in 1994, and acceded to Nagoya Protocol in 2012.

${ }^{4}$ Proclamation No. 299/2002, Environmental Impact Assessment Proclamation, Negarit Gazette, $9^{\text {th }}$ year, Addis Ababa, 11, December 2002, Article 2(2). 
and ecological) in Ethiopia, beginning with clarifying NRs possession/ ownership to understand indigenous people's ABS and authority's management and decisions to realize the law.

\subsection{Recognizing Communal Resource Ownership and Regulating ABS}

Ethiopia constitutionalized many of the ABS providing MEAs and HRAs ratified as discussed above ${ }^{5}$, including some soft laws that encompass the ABS objectives. Still, its domestic legislation doesn't concur with these agreements in addressing the interests of indigenous people ${ }^{6}$. The constitution empowers ethnic groups to self-administration, including governance of their respective regional resources (the constitution, Articles 52 (2) (d)). To this effect, this power is a constitutional right, obliging other laws to complement it. In cases of statutory conflicts, the HRAs prevail over the constitution as well as its subsidiary laws (the constitution, Articles 13 (2) \& 37). Instead of providing explicit legislation, Ethiopia's constitution and other laws stand apart regarding indigenous peoples' benefits about takings of their land and its resources as discussed hereunder.

The constitution complies with the critical issue and substantive indigenous people's rights provided under IEL and HRAs, for example, Article 10 (c) of the CBD, Article 10 (c), Article 5 (2) of the Nagoya protocol, and Article 14 \& 15 (2) of the ILO/169, related to self-determination in regulating ABS. The latter comprises 'certain core values, including non-discrimination, protection of cultural integrity, rights over lands and natural resources, and social welfare for economic well-being and self-government' (Anaya, 2004). Also, procedural rights to ABS, which are further elaborated on in other international instruments ${ }^{7}$, are embedded within ethnic groups' self-determination regimes and constitutional principles: transparency, the rule of law, public participation in development activities (the constitution, Preamble \& Article 12). It divides resources governance powers between the federal government and the regional states.

Intra-state benefit-sharing relations other than genetic resources in Ethiopia are entirely monetary, and they are limited to national-regional state relations alone and excludes indigenous people from the benefits. According to the constitution, the NRs ownership belongs to the public and the state, which the regional states administer based upon federal government laws (the constitution, Articles 51 (5) \& 52 (2) (d)). It also empowers both governments unilaterally and concurrently to collect the resources' benefits, directing detailed regulations on indigenous peoples' protected rights to their ancestral lands (the constitution, Articles 40 (4) (5) \& 39 (3) (5)). According to Article 97 (8) of the constitution, the regional states have powers of "levy and tax collection on income derived from mining operations and royalties and land rentals" in their regions, while it ${ }^{5}$ Ethiopia ratified also the ICCPR in 1976.

${ }^{6}$ Proclamation No. 1/1995, Proclamation of the Constitution of the Federal Democratic Republic of Ethiopia (the constitution), Negarit Gazette, $1^{\text {st }}$ year, no.1, Addis Ababa, $21^{\text {st }}$ August 1995, Articles $9(4)$ and $13(2)$.

${ }^{7}$ Infra note, section 4.4 . 
allows the federal state to have concurrent power of income collection "from large-scale mining and all petroleum and gas operations, and royalties" as provided under Article 98 (3). But, natural resource regulating laws lack clear provisions on shares of benefits that should go to the indigenous people, the regional states, and the federal government from, for instance, the large-scale mining yields ${ }^{8}$. One may argue that regional states can represent the people and act a custodian role to benefit their subjects.

Indeed, regional states administer resources found within their boundary on behalf of the people they represent based upon the federal laws and exercise sovereignty over such resources (the constitution, preamble, articles 8, 46 \& 52). But anything doesn't directly go to the people's pocket from the benefits they and the federation collect to enhance the people's livelihood and cultural needs; or protect or remediate extractive industry-induced hazards to human health, lands, and environment (Boer \& Hannam, 2021). Sectoral laws widened this gap by minimizing the mineral resource administration power of regional states, including denial of indigenous peoples' communal landholding rights, which reveal non-compliance to international instruments and the constitution itself. For example, the Oromia mining Authority reported in 2019 September complaining that it couldn't receive equitable and fair benefit-sharing from LSM. The officials argue that ABS lacks clarity, and sometimes they don't know the amount generated as the industries don't report to them for the absence of law determining the exact proportion (Oromia Mining Authority (OMA), September 2019 (unpublished report)).

Furthermore, the laws fail to consider the indigenous people's established customary norms, traditional settings, and values upon which they claim resource ownership and distribute fruits of natural resources amongst themselves (Abdulahi, 2007). For instance, the rural land proclamation considers indigenous peoples' land and environmental media as the government gives to local communities for common grazing, forestry, and other social services?. It also makes the resources over such lands under the exclusive ownership of the federal government (Article 2 (13)). In both cases, the narration is wrong because the indigenous peoples had owned the resources before any government came into power. And they have been managing and sharing resources, benefits like grasses, water, honey trees, traditionally extracted gold, etc., collectively amongst themselves based on Oromo's customary laws of resource sharing (Beyene et al., 2016). These laws also contradict the CBD and ITPGRFA implementing proclamation and regulation, respectively, in recognizing communities' ownership of their traditional knowledge on genetic resources and sharing benefits from the

${ }^{8}$ Neither the Mining Operations Proclamation (MOP) No. 678/ 2010 as amended by Proclamation $816 / 2013$ and its regulation number $432 / 2018$ nor the income tax proclamation no. $979 / 2016$ and its regulation no.410/2017 provide for benefit share of these organs.

${ }^{9}$ Proclamation No. 456/2005, "Federal Democratic Republic of Ethiopia Rural Land Administration and Land Use Proclamation," Federal Negarit Gazeta, $11^{\text {th }}$ Year No. 44 Addis Ababa. July 15, 2005, Article 2(12). 
same rights (Proclamation No. 482/2006, arts. 9 (1) (3)) ${ }^{10}$. Therefore, although the federal regulations are promulgated to realize international obligations and are expected to acknowledge and enhance the indigenous people's existing customary laws that include the benefit-sharing schemes in their provisions, they bypassed it (Nagoya Protocol, Annex).

Also, the laws lack uniformity on indigenous people's resource holding rights as well as state-community and investor-community relations on ABS. Despite fragmenting resource governance into different sectoral laws, including energy, mine, agriculture, forestry, water and culture, and tourism, most don't address communal non-monetary benefits resulting from collective tenure rights for damages on the ecosystem and the indigenous peoples as well. For instance, except the recent expropriation law ${ }^{11}$, which allows the displaced to be a shareholder in the upcoming development projects in their capacities (Proclamation 1161/2019, Articles 2 (15), 13 (3) \& 16 (4)), mining laws don't treat this benefit distinctly from compensation (Morgera, 2016a: p. 367). But ABS is different from compensation as clearly provided under ILO/169 Article 15 (2). In principle, compensation replaces lost interest while benefit-sharing maintains and enhances the general interests, including supplementing new benefits-such as generating new income sources and increasing the value of land use and resources affected by the development activities (Morgera, 2016a: p. 371).

Thus the Ethiopian laws face a lack of coherence, consistency, and sufficiency in regulating ABS. They also deviate from the ABS rights protected by the IEL, HRAs, and the constitution. These inconsistencies may question the identity of beneficiaries from the ABS mechanisms. The next sub-section analyses whether the laws identify the proper beneficiaries from mineral extractions as compared to global legal standards.

\subsection{Identifying Beneficiaries}

Although it is challenging to conclusively know the actual beneficiaries due to issues aggravating benefit-sharing and the non-exhaustive nature of benefits, intra-state benefit-sharing targets the vulnerable in general (Morgera, 2016a: p. 378). Different global regulations and soft laws define beneficiaries widely from this dimension, including but not limited to indigenous people and local communities, farmers, formal and informal tenure holders, and small-scale fishing communities (Morgera, 2016a: p. 379). Articles 5 (2) and subsequent provisions of the Nagoya protocol elaborate that indigenous people and local communities are beneficiaries in intra-state relations. It entitles them to give their Prior Informed Consent (PIC) and receive shares from benefits fairly and equitably (Nagoya protocol, Articles 15 (1) \& 16 (1)). However, IEL doesn't exhaustively ${ }^{10}$ Regulation no. 169/2009, Access to Genetic Resources and Community Knowledge and Community Rights Council of Minsters Regulation, Federal Negarit Gazette, $15^{\text {th }}$ year, no. 67, Addis Ababa, $9^{\text {th }}$ November 2009, Articles 3-5.

${ }^{11}$ Proclamation 1161/2019, Expropriation of Land Holdings for Public Purpose, Payment of Compensation and Resettlement of Displaced People Proclamation, Federal Negarit Gazette, 25 ${ }^{\text {th }}$ year, no. 90, Addis Ababa, September 23, 2019. 
set criteria to identify local communities entitled to benefit from the treaty (Morgera, 2016a: p. 379). To ease this gap, the human rights reporter listed characteristic features of local communities, which look similar to indigenous people include: self-identification, traditional lifestyle connected biological resources, traditional use and occupation of territories, traditional knowledge (Morgera, 2016b).

Nevertheless, indigenous people are different from local communities. The following characteristics can identify them from the latter: "strong links to territories and surrounding natural resources; distinct social, economic, or political systems, language, culture, and beliefs; and resolve to maintain and reproduce ancestral environments and systems as distinctive peoples and communities" (UN permanent forum on indigenous issues, fact sheet 1). Thus, indigenous people base their origin on the land claimed for development or extractive purpose and are original or aboriginal whose forebears first settled and transferred the resources to them, and they are attached to the customs and traditions of their forebears. In the Ethiopian ABS context, too, indigenous people and local communities may not stand on equal footings, though its genetic resources law recognizes the latter (Proclamation no. 482/2006, Article 2 (9).

Although out of this article's scope, highlighting indigenous vis-a-vis the local community helps understand who the beneficiary is in Ethiopia. In Ethiopia's indigeneity setting, nine regional states and their local administration are named after their ethnic groups, whom they represent (the constitution, Article 47 (1)). All of them are indigenous in their respective regions and localities. The constitution guarantees collective ownership of the land and NRs, which they inherited from their ancestors and have administered them based on their customary laws, and cultures. And the protected rights of the people concerning ABS can be captured from the cumulative reading of the preamble, articles 8 (1), 39 (3) (5), 40 (3-5), and 47 (1) of the constitution. In this sense, irrespective of their occupation, they are real beneficiaries in their collective and individual capacities. Other ethnic members have no right to administer or claim over a region or locality of another ethnic group and are alien to that area with the right to reside and work as a local community, including owning immovable property (the constitution, Article 40 (1)).

Nevertheless, the law established on access to genetic resources and community knowledge and community rights define beneficiaries to be local communities (LCs). Proclamation No. 482/2006, Article 2 (9) reads: “... a human population living in a distinct geographical area in Ethiopia as a custodian of a GR, or creator of a given LC's knowledge." This definition merges LCs with indigenous people instead of the constitutional settings discussed above. Likewise, other laws, including Articles: 2 (1-7) of the expropriation law, 2 (2-6) of the rural land law, and mining laws don't recognize indigenous people as collectively entitled to environmental media by definition and in the main body (Abdulahi, 2007: pp. 117-124). For instance, Except for a licensee's obligation to participate in community development plans, the MOP Articles, 62 (3) V. Articles 5 (5), 33 (1) give 
due attention to incentivize investment rather than protecting the affected communities' benefits. And the laws treat them as an individual equally with aliens, who don't ancestrally belong to a region and don't contribute their traditional knowledge to sustain the resources (Abdulahi, 2007: p. 117). In this context, these national legislations defeat the indigenous people's ABS rights. They also depart from the hitherto jurisprudence of the African Human Rights Commission (AHRC), and its decisions of some cases like Endorois, where the commission decided that the latter are indigenous and entitled to their ancestral resources' benefit sharing (ACHPR \& IWGIA, 2005: pp. 15-19 \& 79-103) ${ }^{12}$.

On the contrary, the recent state practice of Oromia seems to comply with ABS principles and safeguards, which should be scaled up. The new policy direction that has been issued and practiced by the Borana Oromo nation shows that the latter has to benefit collectively from the fruits of investment on their grazing land (Petros Wako, discussant July 2020). This action may solve the existing conflict between customary rules and land administration laws that don't consider communal tenure rights. However, local alien communities may face the risk of exclusion from this benefit as they aren't indigenous to that land (the constitution, Article 47 (1)). In such cases, they may be compensated for their holdings and get equitable access to other benefits using their tenure rights, claiming provisions of the regional Gada economic zone law as local practice ${ }^{13}$. Because, unlike the federal law, Article 8 (5-7) of this law addresses ABS including listings of beneficiaries, which complies with international law. Therefore, the identification of beneficiaries enables to connect them with the benefits they shall be entitled to. The following sub-section critically evaluates the nature and scopes of benefits to be shared.

\subsection{Benefits to Be Shared}

It was stated elsewhere that under international law, benefits to be shared are rarely identified except in the Nagoya Protocol and the CBD's Bonn Guidelines, which lists both natures of benefits though not exhaustive (Nagoya Protocol, Article 5 (4) \& Annex). The non-monetary benefit is significantly more critical to indigenous people than the monetary one (Weinberg and Hauck, 2014). Because they have a historic and traditional attachment to the land of resources that expresses indigenous people's identity, which they don't want to exchange with money. The Oromo indigenous people call their land "lafti keenya lafee keenya," which means "our land defines our soul and who we are." Instead of changing it for monetary value, they prefer to remain there collectively and reserve for their

\footnotetext{
${ }^{12}$ The ACHPR accepted pastoralists, agro-pastoralists and hunter gatherers as indigenous unanimously in 2003 after debating on the report from a committee formed in 2001. (The report is filled with the author). Therefore, the term indigenous should be understood in this research as nations who have been in their ancestral land having their unique connection to their land with their own, language, socio-cultural setup and customary system of resource administration. See Endorois Welfare Council v. Kenya, para. 274.

${ }^{13}$ Proclamation no 226/2020, Proclamation to Establish Gada Special Economic Zone, No. 226/2020, Megalata Oromia, $28^{\text {th }}$ year, no. 11/2020, February 19,2020, Article 8.
} 
future generations (interviewees, 2018) ${ }^{14}$. In responding to such strong beliefs, the HRAs provide that displaced indigenous people should get a return option to their land after development projects completion (UNDRIP, article 10), and the non-monetary ABS safeguards save them from eviction (Morgera, 2016a: p. 354).

But as the nature of benefits is more detailed in legally binding IEL like the Nagoya protocol (Morgera, 2016a: p. 367), states should legislate their national laws similarly. In this regard, Ethiopian extractive industries and NRs laws also lack clarity and coherence in providing lists of benefits. The latter relatively better lists the benefits that LCs can share, while the former is silent about it (Proclamation no. 482/2006, Article 19). However, although not sufficient, the country amended its expropriation law by adding shareholder chance to the evictees (Proclamation no. 1161/2019, Article 16 (3)), following MIDROC's crisis and other public riots demanding $\mathrm{ABS}$, objecting to displacement from their ancestral land due to expansion of Addis Ababa master plan and mine pollutions (Fiseha, 2018). Miner's duty to participate in community development plans is also provided under the mining proclamation ${ }^{15}$. This legislative measure is a promising start to consider non-monetary benefits; nonetheless, they are not sufficient and practicable yet.

Comparatively, some regional states took advanced steps ahead of the federal government to implement the ABS objective in Ethiopia. For instance, monetary and non-monetary benefits are addressed under Article 8 of the recent Gada economic zone law of Oromia. In addition to compensating indigenous people for their property, the same law protects their rights against displacement and allows them detailed non-monetary benefits from the planned development project. The benefits of this law include the priority of services provided in the zone privately or in the group, prior job opportunities, shareholding right in the project undertaken on their land, social services, and other assistance from the development works (Articles 8 (1-7)). It also obliges the administrative agencies to realize these benefits, including enhancing the natural and cultural heritage of the indigenous people (Articles 13 (7-10). Legislating benefit-sharing in this way to give it a legally binding effect, including its benefit natures, justifies "norm diffusion" and eases to distinguish sanctioned violations (Parks \& Morgera, 2015). It also expedites the enforceability of environmental law as sanctions are attached to them in local regulations, as seen in Oromia's regimes. My take here is that Oromia's rules better comply with the international law than the federal ones, revealing how to bottom-up legal diffusion (Parks \& Morgera, 2015: p. 357).

Development-oriented laws should regulate and promote the conservation and sustainability of NRs from which the present and future generations benefit

\footnotetext{
${ }^{14}$ Note that the author was in federal and regional leadership duties and involved to settle the disputes during the years 2014-2018.

${ }^{15}$ Proclamation No. 816/2013, Mining Operations (MOP) (Amendment) Proclamation, Federai Negarit Gazette, $20^{\text {th }}$ year no.27, Addis Ababa, $19^{\text {th }}$ March 2014, Article 62 (3).
} 
reasonably and equitably. In developing countries, especially in an ethnic-based state setting, benefit-sharing transcends community reward through ecosystem services payments not only for their land and NRs stewardship in the already locally established way but also for environmental media's spiritual and sociocultural manifestations (Parks \& Morgera, 2015). As benefits from land are linked to the generational ownership and inalienable attachment to it that defines indigenous people's identity, the domestic laws should have provided their rights to remain in the area notwithstanding the development plans. They should at least explicitly incorporate mandatory substantive and some basic procedural rights requirements (access to information, decision making, and justice) to ABS provided under international law. The following sub-section examines whether the Ethiopian domestic laws properly address the procedural rights related to ABS.

\subsection{The Interaction between ABS and Procedural Rights}

Like in many countries and international fora, there is a remote possibility of procedural rights realization relevant to indigenous people's ABS in Ethiopia (Arjjumend, 2018: p. 102). Among them, PIC demands an understanding that reaches beyond the human rights arena and extends to protecting and access natural resources as a principle (Giupponi, 2018). From the international law and practices, securing free PIC is one of the mandatory requirements to expropriate, develop or decide any project related to land, territories, and resources under ownership and management of indigenous people (ILO/169, Articles 15 (2) \& 16 (2)). They could give their consent when they participate in the decisions of the business that affects their livelihoods starting from the project idea generation level and get informed on its status (UNDRIP, Article 32 (2); Nagoya Protocol, Article 12). However, "lack of a uniform approach, inappropriate timing to conduct consultation, (...), the problem of reacting quickly against violated rights," etc., problems question the effectiveness of PIC procedure, which minimizes or denies to fair and equitable ABS (Sirakaya, 2019). Administrative agencies usually identify the land size, amount of the land covered by forests and vegetation, houses, the right holders, including hearing and deciding on EIA reports to let the others' holding for investment ${ }^{16}$. From my experience of land administration rather than discussing and reaching mutual terms with holders officers of local administration don't resort to exhaust the required criteria on the ground and from the stakeholders physically ${ }^{17}$. Our fieldwork to search truth between public complain and administrative reports proved this fact where sometimes fake data was filled in office and sent to the region or city administration in absence of agreement on pros and cons of the project and the amount of compensation (Oromia Land Administration supervision report, February 2013

\footnotetext{
${ }^{16}$ Proclamation No. 721/2011, Urban Land Lease Holding Proclamation, Federal Negarit Gazette, $18^{\text {th }}$ year no, 4, Addis Ababa, $28^{\text {th }}$ November 2011, Articles 5-17.

${ }^{17}$ The author noticed these gaps from faulty reports during his office works at Urban Land administration in Addis Ababa, 2009-2010 and Oromia 2014-2016, which are on file with him.
} 
(unpublished)).

Consequently, the indigenous people couldn't say "no" or "yes" to planned projects that significantly impact their area as a right holder or partaker of the free PIC requirement (Giupponi, 2018: p. 528). The practice of MIDROC proves this argument that the Guji people didn't consent from the start, let alone negotiate on the benefits they ought to accrue (MOMP, 2019: p. 36). Omitting this duty is a violation of MEAs and bill of rights provisions (Nagoya protocol, Article 6 (2); ICCPR, Articles 18 (1), 19 (2), 27; the ICESCR, Articles 11, \& 15; the CRC, Articles 12-14).

In its custodian capacity, the federal government is duty-bound to inform, involve, and secure consents of the resources' owners-sovereign nations, nationalities, and people (ethnic groups) before letting the mining site to the mine (the constitution, Articles 8 (1), 51 (5) and 89 (2)). Especially, indigenous people have just entitlements to participate in decision making of issues affecting their environment and livelihood in their localities (the constitution, Articles 43 (2), 44 (1); UNDRIP, Articles 18 \& 26). The mining companies, including foreign investors, should regard PIC and be bound by the domestic and global legal regimes applicable to govern the investment (Giupponi, 2018: p. 529). In this context, to be successful, mining companies should get support from indigenous people and reach Mutually Agreed Terms (Nagoya protocol, Article 16 (1)); otherwise, they may be considered enemies to the people and may face sustainability challenges in extractive activities (Bishaw, 2017). According to Gedicks (2015), acquiring public support should start with consulting them before beginning mining projects. Lack of consultations, encroaching indigenous land for mining in general, and LSM, in particular, has increased in the past decades while movements against it grew due to the hazardous effects of the projects and disregard of the indigenous people's ABS rights (Gedicks, 2015). Facts from the MIDROC's mine operations confirm this argument. The mine was closed to community participation ${ }^{18}$.

Similarly, Oromia's Gada economic zone law doesn't provide for the indigenous people's participation in decision making to take their land (proclamation no. 226/2020, Preamble, Articles 5 (3) (4)). Although it aims to involve them in the development processes, omitting their right violates the PIC, consultation, and participation requirements of IEL and indigenous people's rights (CBD, Articles 14 (a-c); UNDRIP, Article 10; Reo Declaration, principle 10). Besides, irrespective of guarantees to ABS's procedural rights provided in the Ethiopian constitution, NRs governing laws and regulations don't consider their particular interests to enjoy the mentioned rights and benefit from the resources they used to manage ${ }^{19}$.

Accessing justice for such violations is also minimal, as observed from pre-

\footnotetext{
${ }^{18}$ Infra, section 5, at notes 160-164 \& section 6.

${ }^{19}$ Proclamation No.300/2002, Environmental Pollution Control Proclamation (EPCP), Federal Negarit Gazette, $9^{\text {th }}$ year, no.12, Addis Ababa, $3^{\text {rd }}$ December, 2002, Article 11(2).
} 
vious practices of the country ${ }^{20}$. Although the affected people can resort to international laws governing the matter as Ethiopia has given direct application of the treaty in its constitution, it would be cumbersome to use such remedies due to lack of awareness, financial and technical capacities (the constitution, Article 9 (2) \& (4); EPCP, Article 11 (2)).

In short, one way of IEL and MEAs implementation at the national level is adopting effective laws. Ethiopian ABS regimes on GRs comply with the CBD and Nagoya protocol provisions. However, they lack adequacy in defining important terms, accommodating collective ABS interests of indigenous people on their NRs, identifying compensation from ABS. Also, they don't comply with IEL in clearly addressing the beneficiaries distinctly from LCs and benefits to be shared. Especially the federal laws fail in properly listing non-monetary benefits and harmonizing indigenous people's ABS procedural rights to reach MATs with the state. Above all, realizing ABS demands the willingness and positive conduct of the state and developers. The next paragraph deals with this issue.

\section{Benefit Sharing and Behavioral Effectiveness}

One can analogize from the preceding discussions that the scope of the ABS principle can apply to mineral resources as the definition of biological diversity encompasses ecosystem with nonliving natural resources (CBD, Article 2 para.7). In this section, the state's administrative and policy decisions are analyzed concerning the laws discussed so far.

The CBD aims to preserve the wide and totality of biological (genetic) information of all living organisms, domestic and wild species on land (Medaglia \& Perron-Welch, 2019: pp. 62-64). The indigenous people have been using and administering, these resources including landed minerals using their traditional knowledge before the government took ownership of such resources (Abate, 2020; Gebre, 2012). The latter's conduct, be it in national policy measures, administrative directives, or appropriate practical operations, should realize fair and equitable ABS duty from such resources to indigenous people and LCs who contribute such knowledge (Nagoya Protocol, Article 5 (5)). The government needs more industries to explore and exploit NRs for the nation's sustainable development. But this activity demands compliance with ABS regimes on the resources (De Brabendere, 2018). Because implementing ABS global duties contributes to a peaceful coexistence of the people with companies and changes the NRs from being curse into developmental inputs and bringing sustainable peace and security in the country (Petrov \& Tysiachniouk, 2019: pp. 3-5).

To this effect, a country's policy, practical implementation directions, and in-

${ }^{20}$ Action Professionals' Association for the People (APAP) sued EPA for its failure to stop leather industries from polluting water and causing public health hazard. In the beginning APAP petitioned for an administrative remedy at EPA, but the latter replied that it couldn't do as there is no standard to compel the industry except negotiation. Next, APAP took the case to First Instance Court, whose ruling was that EPA isn't polluter and cannot be sued. APAPA took the case again to Federal High Court where similar decision was rendered. It raised Article 11(2) of the EPCP cannot apply to EPA since it is not polluter. 
ternational agreements' actions should be as laws on the book. Policy compliance is directly related to the outcome of Agenda 21 commitments on natural resources governance (Nalule, 2020). But a close look section 3.6 (mining) of the Environmental Policy of Ethiopia (1997) tells us that no ABS measures are targeting indigenous people in the policy frameworks. The 1997 Ethiopian environmental and mining policies principles and goals align with the 1972 Stockholm conference and the 1992 Reo declarations in many aspects. But they fail to provide room for preserving indigenous peoples' rights either in monetary or non-monetary benefit forms while these MEAs contain benefit indicators to states, miners, and the local community from mines' development (Agenda 21, chapter one). For example, the mining policy sets academic competence to qualified Ethiopians as a criterion to benefit from employment benefits, while most indigenous people lack that qualification to get that priority (MOP, Article 34 (1) (h)). Because they didn't get the required education in the past regime due to operation and their movable nature as pastoralists, and as they are a collective society, even employing individuals does not satisfy their collective interests (Abdulahi, 2007: p. 86).

Besides, Ethiopian state practice differs from similar African countries. It does not distribute the benefits of mining either in cash or in-kind to the affected community. It shares revenue from tax and royalties with the regions, and there are no benefits from the resources that directly go to the people ${ }^{21}$. Also, the federal-state argues that other opportunities like infrastructure developments benefit should be considered as parts of non-monetary benefits, in addition to employment, but the reality on the ground differs from this policy direction (MOMP, 2019: pp. 38-45). Further, the federal government's unnecessary intervention against regions' constitutional mandates obstructs them from effective administration and utilization of their NRs (MOP, Article 52). It did not decentralize mineral administration power and retained vast power, including licensing strategic minerals, revenue collection, control, and regulating extractive activities (Oromia Mining Authority report, September 2019 (unpublished)). As it is far away from the mining sites, continuous monitoring and follow-up of extractive industries is no easy task for the federal institution in charge. These problems force the regional states to bear cost burdens of infrastructural damages like road, pollution from mining-induced poisonous chemicals that deteriorate the people's health and livelihood, while the laws prohibit ecological disruption (OMA), September 2019.

Mining industries benefit the local community by being a market for agricultural products, creating employment opportunities for youth in different sectors, and building social interactions to realize non-monetary ABS in other jurisdictions (World Bank, 2015). Ghana's lesson shows that ABS reaches the affected community and is under good management in mining rent, though the rural population did not get rid of absurd poverty (Muigua, 2019). Likewise, goldmine ${ }^{21}$ Proclamation No.979/2016, Federal Income Tax Proclamation, Negarit Gazette, 22 ${ }^{\text {nd }}$ year, no.104, Addis Ababa, $18^{\text {th }}$ August 2016, Articles 36-44. 
companies in Tanzania, South Africa, Guinea, Mali, and Burkina Faso are one source to improve local communities' livelihoods (Nalule, 2020: pp. 7-20). Natural resources in Nigeria, too, boost the national economy beyond five-percent, but environmental damage threatened farmers' and fisherfolks' livelihoods, including those who depend on NRs (World Bank, 2015). The MIDROC case concurs with the oil company's pollution scenario that contaminated water, soil, and air and affected the Ogoni indigenous people's economy (World Bank, 2015).

MIDROC had been working with EPRDF ruled armed forces to suppress any public question and demonstrations against the company's acts or omissions in the last decades (MOMP, 2019: pp. 43-46). The explored mineral deposits, including gold, are located mostly in Oromo land ${ }^{22}$. Mineral extraction may consume more of their land in the next decades and the tension will continue unless grudges of indigenous people get solutions by involving them in upcoming projects to reach MATs on ABS (Abera, 2016). It is mentioned under the problem above that the state forcefully removed the Guji-Oromo from the site without consulting, educating about consequential effects of the project, payment of any compensation, and fulfilling their ABS rights in 1998 and 2009 (MOMP, 2019: pp. 42-44). And this trend continued until the public's frequent complaints and protests, which resulted in conflicts, forced the government to suspend the mining license of the industry in early May 2018 for the second time (Ethiopia Observer, 2018). Despite the existence of necessary legal grounds to establish corporate environmental, civil and criminal liability, to make the company accountable, political unwillingness sidelined public questions to ABS, health, and environmental rights (Bishaw, 2017). States activities should create a binding interplay between corporations and human rights protection and open rooms for corporate responsibility in practice (De Brabendere, 2018: pp. 3-4). Hence, Ethiopia should learn from Ghana's best practices and get rid of its own and Nigeria's conduct.

In summary, mineral policies and administrative measures of Ethiopia fail to meet fair and equitable ABS requirements. Although NRs are basic tools to bring developments, the state's and extractive industry's conduct deviate from the commitments of Ethiopia to realize the ABS regimes through the SDGs 2, 15 and their corresponding objectives. Unfulfilling ABS to the needy negatively impacts the environment and the livelihood of the people as discussed in the following section.

\section{Benefit Sharing and Ecological Effectiveness}

The preceding section argued that the actors' actual practices negate Ethiopia's ABS and pollution prevention duties. The non-observance of IEL obligations may impact the survival and the ecosystem services. This section analyses the impacts of the alleged conduct on the environmental media.

\footnotetext{
${ }^{22}$ Tables 27-29 of the compendium show that Oromia is the place for occurrences of Most Gold and other mineral deposits. And the Ethiopian government alienated more than 11 sites from 1993-2016, out of which 8 are in Oromia and from this 4 are around Adola, near Laga-Dambi.
} 
Environmental regimes should be institutionally and ecologically effective to adequately address ecological conservation so that the next generation secures its benefits. But human actions caused 22.4 percent to 35.5 percent of the land area degradation in the past fifteen years, on which indigenous people of Africa and Ethiopia depended for their livelihood (SDGs report, 2019). Among many factors that aggravate degradation, extractive industries are one of the major ones, which damage the ecosystem by their nature (Jackson \& Buhrs, 2015). Especially, frequent impacts of mining on the indigenous people's holdings include land degradation, deforestation, and mine-induced pollution (Wolff, 2014). Adopting and implementing legal and policy materials on land degradation neutrality is critical to evaluate and respond to such problems (Boer \& Hannam, 2021: p. 4). Accordingly, evaluating the regime's effectiveness should combine the following mutually interconnected IEL effectiveness issues: outputs (legal aspect), the outcomes (state conduct), and impacts (ecological changes) (Sand, 2017). Thus, in identifying and solving the regime's problem concerning indigenous people's ABS, one should combine institutional ability (legal and behavioral) and ecological effectiveness (Sand, 2017).

The absence of binding legislation that employs indigenous knowledge in environmental governance, especially land and soil, as an institution and minimal corporate responsibility concerns to ecological conservation are core normative and practical problems to ecological effectiveness at the international level (Boer \& Hannam, 2021: pp. 3-7). Because although the indigenous people have a share in degradation, on the one hand, their indigenous knowledge and customary norms contributed to preserving the ecological media till the technology-born operations began to consume a vast area of NRs. Domestic legal compliance with global regimes, implementation of the same, and environmental conservation enhances the environment (Sand, 2017), positively contributing to indigenous people's ABS and following that political system's stability. Nevertheless, failure of one or more of these elements ends up in denial of ABS, resulting in mob justice.

Some recommend that "ABS in the IEL context and the Clean Development Mechanism/REDD+ in the climate context have become helpful as the emerging parts of market or payment concepts for ecosystem services in times of using NRs for SDGs achievements (SDGs report, 2019: p. 168). But others argue that this system may depart the ABS from its original purpose, which is a non-marketbased scheme aimed at development and equity (ILA, 2002: p. 206). Nonetheless, notwithstanding the economic tool integrated approach as provided in 2030 SDGs along with precautionary measures against pollution, pre-designation of forest reserves, and building investor-indigenous people trust enable ABS (Boer \& Hannam, 2021: p. 2). To this end, scholars suggest the incorporation of nonbinding legal frameworks into nationally binding laws to harness ecological effectiveness (Boer \& Hannam, 2021: pp. 13-15).

Without prejudice to national sovereignty over NRs and private developers' role in contributing to the country's economic growth, indigenous people's rights 
to access and conserve the environment, including the benefit from their ancestral resources to realize the needs of their off-springs enhances ecological effectiveness (Barrel, 2016). However, Ethiopia's practice seems far from the principles of equity and sustainability in NRs use. The indigenous people's traditional knowledge to guard against resource depletion, preserving capacity that, somehow, furthers their economic, social, and potentially cultural well-being has not been considered. According to the MOP report (2019), MIDROC cleared offindigenous forests without planting any trees to replace them and confiscated farmlands, and bulldozed people's coffee trees for site expansion. The public was even denied access to the cleared forest and coffee leaves for domestic use (MOMP, 2019). Contaminated soil and water from poisonous hard metals like mercury and arsenic reduced the quality and amount of agricultural produce (EPHI \& MOMP, 2018). As a result, the people couldn't accrue from exploiting the resource and are suffering from its depletion and extinction of wildlife and edible flora (MOMP, 2019). This fact immerses the country into the dilemma of international regime tensions in denying them $\mathrm{ABS}$ and reinstate the people's livelihood (Boer \& Hannam, 2021: p. 4).

In short, ecological effectiveness and ABS seems to continue ideal at the national level in Ethiopia and Africa, contrary to other continents (Petrov and Tysiachniouk, 2019: pp. 14-16). Both federal and local governments should have realized $\mathrm{ABS}$ as provided in their constitutions or laws rather than complicating matters to indigenous people, just like what was observed in the Ogeik case in Kenya (Joseph Letuya and 21 others v AG and 5 others (Ogeik), 2012). Ethiopia's laws oblige investors to act with due diligence in protecting the environment. Still, non-compliance to ABS-related global norms affects the vulnerable in many ways. Many people surrounding the mine live in deteriorated and substandard houses compared to their neighbors due to physical disability caused by the toxicity of mine to their health and environment, economic loss, and less yield as in the Ogeik case (MOMP, 2019; EPHI \& MOMP, 2018).

\section{Conclusion}

In this article, I attempted to identify and analyze normative gaps in the Ethiopian laws relating to fair and equitable benefit-sharing, and to figure out whether these gaps can be remedied to induce the country to better comply with its international obligation. Accordingly, it analyzed national legislation, the government's conduct, and their effects on the ecological protection duty of the country under international law. And it revealed that there are gaps to be remedied as summarized hereunder.

Ethiopian laws fail to include details of ABS requirements provided under international law. Ethiopia GRs laws with ABS provisions to implement CBD and ITPGRFA six years before it acceded to Nagoya protocol. However, the benefits provided in the domestic laws are not compatible with the protocol. The latter and other international instruments regulating ABS are detailed and cover a 
wide range of benefit-sharing schemes. But Ethiopian national laws are inadequate to implement the latest progress and obligations listed under the global norms. They set aside provisions of ABS for indigenous people and provide it only for local communities. By doing so, they neglect the importance of indigenous people's knowledge, customary laws, institutions for natural resource management, and their collective access to a fair and equitable share of benefits from the fruits of their ancestral resources. Also, legal fragmentation and lack of coherence exist between federal and regional laws as compared to international duties of the country.

Also, the state's conducts violate IEL regulations. The policy documents allow transferring communal lands to investors disregarding indigenous people's procedural and substantive rights to involve and benefit from the ABS process. The state's paltry practices also include confusing ABS with compensation, while using interpretative convergence of public regulations, i.e., cumulative readings of international instruments with domestic laws may solve the statutory gap to serve core normative values. The practical irregularities increased the indigenous people's vulnerability to hunger and livelihoods deficits (Beyene et al., 2016: p. 80). This act in turn adversely impacts businesses' smooth flow to achieve SDGs, as observed in the MIDROC gold's operation suspension since 2017.

What is more, failure to take precautionary and preventive measures against goldmine's damaging effect on the living environment shows the ecological ineffectiveness of international law in Ethiopia to benefit indigenous people. The problems go beyond ABS and affected public and animal health, creating environmental pollution.

As I conclude, normative and practical gaps to comply with international legal regimes in implementing ABS concepts, identifying proper beneficiaries, and listings of benefits in the Ethiopian legal context. Instead of providing explicit legislation, its constitution and other laws stand apart regarding indigenous people's share of benefits from resources extracted from their land.

As a way forward, Ethiopian laws need amendments to implement the country's ABS obligations on natural resources. Explicit mention of the benefits in the laws may oblige Ethiopia to comply with its global duties; otherwise, indigenous people's issues remain under the fate of arbitrary administrative decisions. Legislative reform also enables the state to observe duties, safeguards, and ABS principles provided in both IEL and HRAs. Besides, there should be laws that create a binding relationship between corporations and the indigenous people in terms of non-monetary benefits to sustain the latter on their lands without affecting the ongoing development activities (De Brabendere, 2018). The laws should indicate collective benefits and benefits that should address individual persons' distinctly state duty of providing infrastructures. Going forward, the government should refrain from endorsing policy measures that contradict the country's international law duties and its constitution. Also, the policy directions should treat companies in the way that they fulfill the ABS as provided under IEL and HRAs. 


\section{Acknowledgements}

The author gratefully acknowledges Professor Qin Tianbao, Professor Otto Spijkers and the anonymous reviewers for their constructive comments on the early draft of the manuscript

\section{Conflicts of Interest}

The author declares no conflicts of interest regarding the publication of this paper.

\section{References}

Abate, A. G. (2020). The Effects of Land Grabs on Peasant Households: The Case of Floriculture Sector in Oromia, Ethiopia. African Affairs, 119, 90-114. https://doi.org/10.1093/afraf/adz008

Abdulahi, M. (2007). The Legal Status of Communal Land Holding System in Ethiopia: The Case of Pastoral Communities. International Journal on Minority and Group Rights, 14, 85-125. https://doi.org/10.1163/138548707X181566

Abera, D. M. (2016). Mineral Policy and Status of Mineral Investment in Ethiopia. China Mining Conference 2016, Tianjin, 1-16. http://www.cgs.gov.cn/ddztt/kydh/2016kydh/gjhzcgxz/201609/P0201609265226046340 37.pdf

ACHPR \& IWGIA (2005). Report of the African Commission's Working Group of EXperts on Indigenous Communities. Copenhagen: Eks/Skolens Trykkeri. https://www.iwgia.org/images/publications/African Commission book.pdf

Alces, P. A. (2003). The Unruliness of Rules (p. 129). Faculty Publications. https://scholarship.law.wm.edu/facpubs/129 https://doi.org/10.2307/3595343

Anaya, J. (2004). Indigenous Peoples in International Law (2nd ed., pp. 1-408). Oxford: Oxford University Press.

Arjjumend, H. (2018). Recognition of Indigenous Peoples in Access and Benefit Sharing Abs Legislation and Policies of the Parties to the Nagoya Protocol. BRICS Law Journal, 5, 86-113. https://doi.org/10.21684/2412-2343-2018-5-3-86-113

Barrel, V. (2016). National Sovereignty over Natural Resources, Environmental Challenges, and Sustainable Development. In E. Morgera, \& K. Kulovesi (Eds.), Research Handbook on International Law and Natural Resources (pp. 1-25). Cheltenham: Edward Elgar.

Beyene, F. et al. (2016). Assessment of Customary Land Administration and Natural Resources Management in the Pastoral areas of the Oromia Regional State (pp. 1-90). Addis Ababa.

Bishaw, A. (2017). An Appraisal of the Legal Bottom-Line of Corporate Environmental Responsibility in Ethiopia. Bahir Dar University Journal of Law, 7, 223-260.

Bodansky, D. (2010). The Art and Craft of International Environmental Law (pp. 1-359). Cambridge, MA: Harvard University Press.

Boer \& Hannam (2021). Land Degradation Neutrality and SDG 15. In N. Kakar, \& N. Robinson (Eds.), Implementation of the Sustainable Development Goals, 1-13.

Cabrera, J., \& Fred-Perron, M. (2018). Current Status and Future Research Agenda on Benefit-Sharing in International Sustainable Development Law. Journal of Korean Law, 17, 179-216.

De Brabendere, E. (2018). Human Rights and International Investment Law. In M. Kra- 
jewski, \& R. Hoffmann (Eds.), Grotius Centre Working Paper Series, No. 2018/075-HRL, 1-22. https://ssrn.com/abstract $=3149387$

EPHI \& MOMP (2018). Legadembi Mining and Community Health Study: Technical Report 2018. Addis Ababa, 1-121.

Ethiopia Observer (2018). MIDROC's Gold Mining Permit Suspended after Protests. Ethiopia Observer. https://www.ethiopiaobserver.com/2018/05/09/midrocs-gold-mining-permit-suspended

Ethiopian National Planning Commission, Central Statistical Agency (2017). Compendium of Environment Statistics. Addis Ababa.

Fiseha, A. (2018). Federalism and Development: The Ethiopian Dilemma. International Journal on Minority and Group Rights, 25, 333-368. https://doi.org/10.1163/15718115-02503004

Gebre, A. (2012). The Dynamics of Land Transaction Practices among the Karrayu Pastoralists in the Upper Awash Valley of Ethiopia: The Cases of Abadir and Merti Communities. East African Social Science Research Review, 28, 59-89.

https://doi.org/10.1353/eas.2012.0003

Gedicks, A. (2015). Transnational Mining Corporations, the Environment, and Indigenous Communities. Brown Journal of World Affairs, 22, 129-152.

Giupponi, B. O. (2018). Free, Prior, and Informed Consent (fpic) of Indigenous Peoples before Human Rights Courts and International Investment Tribunals: Two Sides of the Same Coin? International Journals on Minority and Group Rights, 25, 485-529. https://doi.org/10.1163/15718115-02503005

Gorobets, K. (2020). The International Rule of Law and the Idea of Normative Authority. Hague Journal on the Rule of Law, 12, 227-249. https://doi.org/10.1007/s40803-020-00141-3

ILA Resolution 2002/3 (2002). New Delhi Declaration of Principles of International Law Relating to Sustainable Development, 70th Conference. New Delhi, 299-305.

Jackson, W., \& Buhrs, T. (2015). International Environmental Regimes: Understanding Institutional and Ecological Effectiveness. Journal of International Wildlife Law and Policy, 18, 63-83. https://doi.org/10.1080/13880292.2014.957030

Joseph Letuya and 21 Others v AG and 5 Others. ELC Civil Suit. 821 (2012). http://kenyalaw.org/caselaw/cases/view/95729

Medaglia, J. C., \& Perron-Welch, F. (2019). The Benefit-Sharing Principle in International Law. Journal of Intellectual Property Law \& Practice, 14, 62-76. https://doi.org/10.1093/jiplp/jpy162

MOMP (2019). A Report on a Study on Socio-Economic Impacts of MIDROC Gold Mining Industry, Addis Ababa.

Morgera, E. (2016a). The Need for an International Legal Concept of Fair and Equitable Benefit Sharing. EJIL, 27, 353-383. https://doi.org/10.1093/ejil/chw014

Morgera, E. (2016b). Under the Radar: Fair and Equitable Benefit-Sharing and the Human Rights of Indigenous Peoples and Local Communities Related to Natural Resources. Benelex Working Paper No. 10. https://doi.org/10.2139/ssrn.2887803

Morgera, E. (2017). Fair and Equitable Benefit-Sharing: History, Normative Content, and Status in International Law. In E. Orlando, \& L. Krämer (Eds.), Encyclopedia of Environmental Law: Principles of Environmental Law. https://doi.org/10.2139/ssrn.2956927

Muigua, K. (2019). Reflections on Managing Natural Resources and Equitable Benefit Sharing in Kenya. Law Society of Kenya Journal, 15, 1-42.

http://kmco.co.ke/wp-content/uploads/2019/09/REFLEC 1.pdf 
Nalule, V. (2020). Mining and the Law in Africa: Exploring the Social and Environmental Impacts. Berlin: Springer. https://doi.org/10.1007/978-3-030-33008-8

NPC \& CSA (2017). Compendium of Environment Statistics. Addis Ababa.

Nyamwaya, C. (2013). Benefit-Sharing on Extractive Natural Resources with Community in Kenya (pp. 1-49).

Parks, L., \& Morgera, E. (2015). The Need for an Interdisciplinary Approach to Norm Diffusion: The Case of Fair and Equitable Benefit-Sharing. RECIEL, 24, 353-367. https://doi.org/10.1111/reel.12143

Petrov, N. A., \& Tysiachniouk, S. M. (2019). Benefit Sharing in the Arctic: A Systematic View. Resources, 8, 1-16. https://doi.org/10.3390/resources8030155

Sand, P. H. (2017). The Effectiveness of Multilateral Environmental Agreements: Theory and Practice. International Environmental Law-Making and Diplomacy Review, 16, 1-26.

SDGs Report (2019). UN Sustainable Development Goals Report. http://www.un.am/up/library/SDG Report 2019.pdf

Sirakaya, A. (2019). Balanced Options for Access and Benefit-Sharing: Stakeholder Insights on Provider Country Legislation. Frontiers in Plant Science, 10, 1175. https://doi.org/10.3389/fpls.2019.01175

UNDRIP (2007). GA Res. 61/295. 2 October 2007, 12 September 2007, art 28.

UN Permanent Forum on Indigenous Issues. https://www.un.org/esa/socdev/unpfii/documents/5session factsheet1.pdf

Weinberg and Hauck (2014). People, Power and the Coast: Towards an Integrated, Just and Holistic Approach. In R. Weinberg, \& M. Hauck (Eds.), Sharing Benefits from the Coast: Rights, Resources and Livelihoods (p. 143). Cape Town: UCT Press.

Welfare Council v. Kenya (Endorois Case). Communication No. 276/2003, 25 November 2009.

Wolff, F. (2014). The Nagoya Protocol and the Diffusion of Economic Instruments for Ecosystem Services in International Environmental Governance. In S. Oberthir, \& G. K. Rosendal (Eds.), Global Governance of Genetic Resources: Access and Benefit Sharing after Nagoya Protocol (pp. 132-177). Milton Park: Routledge.

World Bank (2014). MIDROC Gold Mine PLC: Overview and Contribution. https://www.worldbank.org/content/dam/Worldbank/Event/Africa/Ethiopia\%20Extrac tive\%20Industries\%20Forum\%202014/5a MIDROC.pdf

World Bank (2015). Socioeconomic Impact of Mining on Local Communities in Africa (pp. 132-134). Report No. ACS14621, Washington DC: World Bank. https://openknowledge.worldbank.org/handle/10986/22489

Zheng, X. (2019). Key Legal Challenges and Opportunities in the Implementation of the Nagoya Protocol: The Case of China. RECIEL, 28, 175-184.

Zmyvalova, A. E. (2018). Indigenous Peoples of the Russian North and Their Right to Traditional Fishing. International Journal on Minority and Group Rights, 25, 51-83. https://doi.org/10.1163/15718115-02501004 